\title{
International financial cooperation to address the Latin American economic crisis ${ }^{1}$
}

\author{
José Antonio Ocampo
}

\begin{abstract}
The current economic crisis will be remembered, not only as the worst since the Great Depression, but also for the limited multilateral financial cooperation agreed, particularly for middle-income economies. Several Latin American countries have benefited from flexible and emergency credit lines from the International Monetary Fund (IMF), in addition to other IMF instruments. Members of the Latin American Reserve Fund (known by its Spanish acronym, FLAR) can access its resources. Multilateral development banks have taken steps to support Latin American countries, but resources are limited. The Inter-American Development Bank (IDB) and the Development Bank of Latin America (CAF) have reached their lending capacity limit and need to be capitalized. The World Bank has increased its lending to the region, but these loans amount to less than those granted in 2009-2010. The actions of the Central American Bank for Economic Integration (CABEI) are noteworthy, thanks to its recent capitalization.
\end{abstract}

\section{Keywords}

Economic crisis, international financial institutions, development banks, international cooperation, external debt, Latin America

\section{JEL classification}

$$
\text { F34, F55, G15, O19 }
$$

\section{Author}

José Antonio Ocampo is a Professor at School of International and Public Affairs of Columbia University. Formerly, he was Under-Secretary-General for Economic and Social Affairs of the United Nations, Executive Secretary of the Economic Commission for Latin America and the Caribbean (ECLAC) and Minister of Finance of Colombia. Email: ocampo.joseantonio@yahoo.com.

\footnotetext{
This paper was prepared for the United Nations Development Programme (UNDP) and published as part of its COVID-19 Policy Documents Series (UNDP LAC C19 PDS N7). An updated and slightly shorter version is published here. Given the speed with which the situation is evolving, it is analysed in the light of the information available and policy decisions taken up to 1 June 2020. The author wishes to thank Marcela Meléndez and Miguel Ángel Torres for their comments on previous versions, and María Luisa Montalvo and Víctor Alejandro Ortega for their collaboration on its drafting.
} 


\section{Introduction}

The coronavirus disease (COVID-19) pandemic, the worst in a century, has engendered a global economic crisis that has been described by the Managing Director of the International Monetary Fund (IMF) as the worst recession since the Great Depression of the 1930s (Georgieva, 2020). The containment measures, adopted to manage the public health problems, have had a profound effect on the economy, as they have paralysed "non-essential" activities, which may account for $50 \%$ or more of economic activity in many countries. The turmoil in the financial markets has also been profound and prompted the worst flight in history of portfolio capital from emerging economies, although the markets have recovered somewhat recently. At the same time, international trade has contracted sharply, deepening the process that had already started in late 2019 as a result of the global economic slowdown and the "trade wars", especially between the United States and China. In addition to this, the prices of an important group of commodities have dropped, reinforcing the negative trend seen over the last five years. Exports of services have also fallen, due in particular to the paralysis of tourism and air passenger traffic. In addition, remittances from migrant workers to their countries of origin will plummet and new controls are being imposed on international migration.

The pandemic arrived relatively late in Latin America, but began to have significant effects in terms of infected people and the mortality rate in several countries, especially Brazil. ${ }^{2}$ In economic terms, the pandemic hit the region after five years of slow economic growth, which can be described as a "lost half-decade" (Ocampo, 2020). Apart from the direct impact of the containment measures decreed in several countries, or those that people have adopted voluntarily to protect themselves, the economies of the region are also feeling the effects of the global crisis. Latin America will suffer the steepest drop in economic activity in the developing world, echoing the pattern that it has experienced in recent decades, although with varying effects among the different countries. The 2020 recession will, moreover, be the worst since the Second World War, and there is thus the danger (and almost the certainty) that the lost half-decade will be turn into another lost decade.

Against this adverse backdrop, international economic cooperation has been very weak so far, in contrast to the strong multilateral collaboration led by the Group of 20 (G20) during the North Atlantic financial crisis of 2008-2009. ${ }^{3}$ This article analyses the discussions surrounding and the decisions taken on international financial cooperation and the extent to which it benefits Latin America. ${ }^{4}$ The article is divided into six sections, the first of which is this introduction. As a background, section II offers some considerations on the global context as well as that of Latin America. A general analysis of international financial cooperation is presented in section III. The analyses of monetary cooperation and the support from multilateral development banks and their impact on Latin America are discussed in detail in sections IV and V. Some brief conclusions are set out in section VI.

Academics have made enormous contributions to the ongoing discussions. ${ }^{5} \mathrm{I}$ am unable to do them justice here, although I will refer to proposals made by some authors. The analysis will be rooted in the international discussions of and decisions taken by the major multilateral agencies to address the financial problems faced by emerging economies.

2 See the updates by IDB on the spread of the pandemic in the region in IDB (2020).

3 I prefer this term to the more commonly used "global financial crisis" because, although its effects were global, the crisis was concentrated in the United States and Western Europe.

4 My analysis of Latin America does not include Cuba, which is not a recipient of the international financial cooperation under analysis, or Haiti, which is, but through special mechanisms for very low-income countries, to which I make only marginal reference. The Bolivarian Republic of Venezuela also faces particular problems in its dealings with some of the international financial institutions mentioned throughout this article.

5 See, among many others, Baldwin and Weder di Mauro (2020), Levy (2020), Stiglitz and others (2020), and my contributions with other colleagues in Gallagher, Ocampo and Volz (2020), Gallagher and others (2020), and Griffith-Jones, Marodon and Ocampo (2020). 


\section{The global and Latin American context}

The recent IMF World Economic Outlook (IMF, 2020a) report projects a decline in global gross domestic product (GDP) based on market exchange rates of $4.2 \%$ in $2020 .{ }^{6}$ This is the result of falls of between $5 \%$ and $7 \%$ in the major developed economies and $5 \%$ or more in the emerging and developing economies, with Latin America as the worst performing region among the latter group of countries. The sharp downturn reflects the devastating effects of the pandemic containment measures on economic activity: quarterly contractions that were already severe in the first quarter ${ }^{7}$ and that may reach double digits in many economies in the second quarter. The basic IMF forecast assumes that these effects will gradually dissipate, but clearly there is uncertainty as to whether there will be the medical means to prevent further outbreaks.

This crisis, which is truly global in scope, will certainly be more severe than that suffered by the global economy during the North Atlantic crisis (-2.0\% at market exchange rates in 2009, according to IMF figures), which did not occur in a large group of emerging and developing economies. Compared to the Great Depression, the current economic contraction has happened more quickly, but may be less deep and, above all, less protracted. ${ }^{8}$ The basic IMF projection is that growth will be $5.4 \%$ in 2021 , which would more than offset the 2020 recession, although not in all countries. However, if it takes longer than expected to contain the pandemic, IMF estimates that global output would be an extra $3 \%$ lower in 2020, and, if this is combined with a second outbreak in 2021, output would be almost $8 \%$ lower than projected in 2021.9

In light of this, developed countries have been adopting aggressive measures in terms of increasing public spending, reducing or delaying tax payments, and providing liquidity, and credit lines and guarantees for the business sector. In both fiscal and monetary terms, IMF concludes that the packages are stronger than those adopted to deal with the North Atlantic crisis, although with differences between countries (IMF, 2020b and 2020c). By contrast, China's recovery measures have been less pronounced than those adopted in 2009, because it has a smaller fiscal margin today, an issue that affects many emerging and developing economies more generally.

Initially, the effects on the financial markets were devastating. However, thanks to the central banks' forceful interventions, the market falls were less pronounced than in 2008-2009, and even led to a partial recovery from late March (IMF, 2020b). A notable effect was the worst portfolio outflows from emerging economies in history, exceeding US\$ 100 billion (Brooks and Fortun, 2020 and IMF, 2020b). However, as will be seen in section IV, although risk spreads for these economies have remained high, bond yields and the cost of new financing have fallen to relatively moderate levels thanks to the decline in benchmark interest rates (those of United States Treasury Bonds), and several countries began to issue bonds on the international markets in mid-April, much sooner than in past crises.

Another effect of the crisis has been a sharp contraction in international trade. Trade volumes and value, which began to fall in late 2019, have plunged further. ${ }^{10}$ The World Trade Organization (WTO, 2020) expects that trade volume will fall by between $13 \%$ under the baseline scenario and $32 \%$ under the most pessimistic one. The crisis may lead to the destruction or shortening of many international value

6 The IMF headline estimate is $-3.0 \%$, calculated at purchasing power parity prices. This estimate is not comparable with those based on market exchange rates used by the United Nations, the World Bank and most private analysts.

7 Down $6.8 \%$ in the case of China, the country that was affected the earliest, $4.8 \%$ in the United States and 3.8\% in the eurozone.

8 This is particularly true of the United States, which saw three consecutive years of economic contraction during the Great Depression, with a cumulative downturn of $27 \%$ according to the historical figures compiled by Maddison (2010), only returning to 1929 levels of growth a decade later.

9 These estimates are at purchasing power parity prices.

${ }^{10}$ See the statistics published monthly by the Netherlands Bureau of Economic Policy Analysis (CPB). These figures indicate that growth in the 12-month moving average of the volume of global exports was negative from October 2019, while that of global export values has been negative since August 2019 (CPB, n/d). 
chains. For this reason, trade may recover much more slowly than it did in 2010, which more than offset the fall seen in 2009. With regard to commodities, the crisis has caused oil and other energy prices to plummet, a more modest fall in basic metals' prices and diverse trends for agricultural products. ${ }^{11}$

Latin America is dealing with these serious external shocks after five years (2015-2019) of anaemic growth, the worst since the Second World War, even worse than the five years of slowest growth during the Latin American debt crisis and the five years after the 1997 Asian financial crisis (see figure 1). In the last five years, regional GDP growth barely reached $0.2 \%$ (0.9\% if the Bolivarian Republic of Venezuela is excluded). This poor performance reflects not only economic problems, but also complex political crises and transitions in several countries.

Figure 1

Latin America: GDP growth, 1950-2020a

(Percentages)

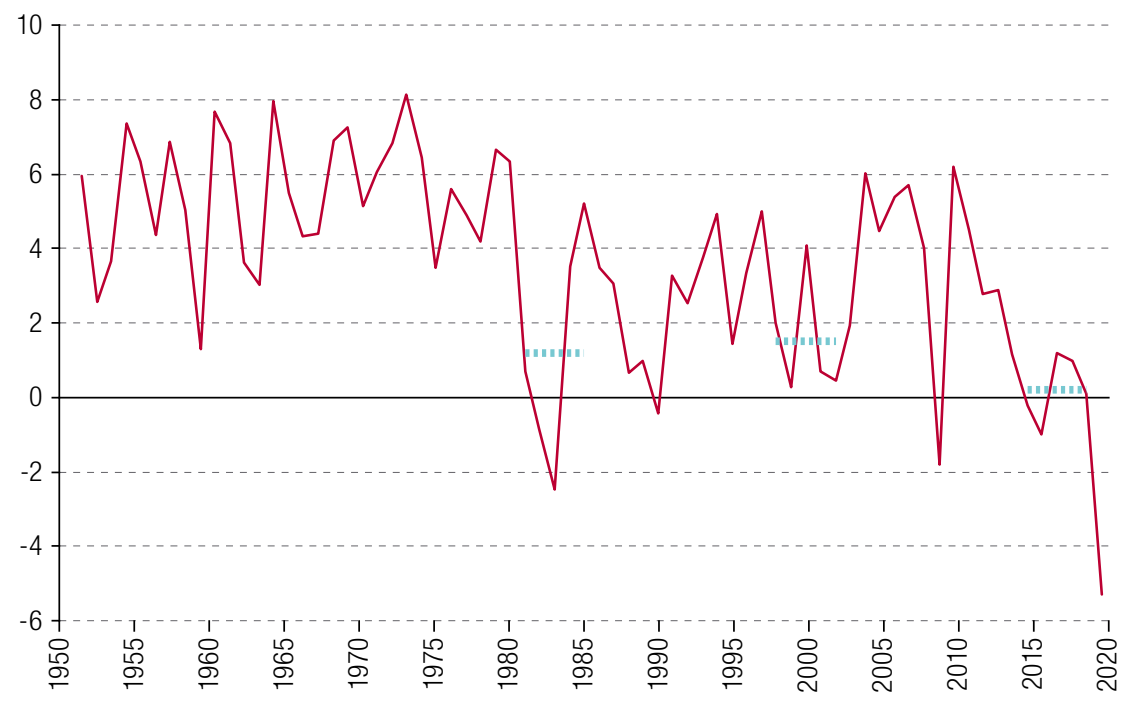

Source: Prepared by the author, on the basis of data from the Economic Commission for Latin America and the Caribbean (ECLAC). Note: The dotted lines indicate average annual growth during the aforementioned three five-year periods of low growth, specifically 1980-1985, 1997-2002 and 2015-2019.

a Figures for 2020 are estimates.

However, Latin America's economic problems began long before the recent wave of economic and political instability. Economic growth in the region over the last three decades (1990-2019) was only $2.7 \%$ per year, half of that seen in the 30 years preceding the lost decade (average annual growth was $5.5 \%$ in the period 1950-1980). Almost all the economies of the region have grown less than during those 30 years (with the exception of Chile, the Plurinational State of Bolivia and Uruguay); the downturn was particularly serious in the Bolivarian Republic of Venezuela, Brazil and Mexico. This indicates that, regardless of the current crisis, the region's development patterns need to be considered in depth.

All the multilateral organizations (World Bank, 2020b; ECLAC, 2020a and 2020b; IMF, 2020b; Nuguer and Powell, 2020) forecast a major recession in Latin America in 2020, with only a partial recovery in 2021. As shown in table 1, these organizations expect a drop of around $5 \%$ for the region as a whole, with particularly severe downturns in Argentina, the Bolivarian Republic of Venezuela, Brazil, Ecuador and Mexico. Among the larger countries, Chile and Peru will be affected less and Colombia

\footnotetext{
${ }^{11}$ IMF (2020f) data on commodity prices indicate that the price of energy products has declined by $59.5 \%$ compared to the average for 2019 (oil prices are down by 65.0\%), basic metals by $14.7 \%$ and agricultural products used as industrial inputs by $9.4 \%$, but that food and beverage prices have fallen by just 5.5\%. World Bank (2020a) projections for the whole year follow this pattern.
} 
will perform comparatively well according to these projections. ${ }^{12}$ In general, the smaller countries, with the exception of Ecuador, will perform better. For the region as a whole, the 2020 recession will be the worst since the Second World War (much worse, in fact, than that of 1983, the worst year of the Latin American debt crisis) and one of the most painful in history. ${ }^{13}$

Table 1

Latin America and the Caribbean: economic growth in 2019 and projections for 2020-2021 (Percentage growth rates)

\begin{tabular}{lccccc}
\hline & \multicolumn{2}{c}{ ECLAC } & & IMF & World Bank \\
\cline { 2 - 3 } \cline { 5 - 6 } & 2019 & 2020 & & 2020 & 2020 \\
\hline Argentina & -2.2 & -6.5 & & -5.7 & -5.2 \\
\hline Brazil & 1.1 & -5.2 & & -5.3 & -5.0 \\
\hline Colombia & 3.3 & -2.6 & & -2.4 & -2.0 \\
\hline Chile & 1.1 & -4.0 & & -4.5 & -3.0 \\
\hline Ecuador & 0.1 & -6.5 & & -6.3 & -6.0 \\
\hline Mexico & -0.1 & -6.5 & & -6.6 & -6.0 \\
\hline Peru & 2.2 & -4.0 & & -4.5 & -4.7 \\
\hline Venezuela (Bolivarian Republic of) & -25.5 & -18.0 & & -15.0 & n.d. \\
\hline Latin America and the Caribbean & & & & -5.2 & -4.6 \\
\hline 2020 & 0.1 & -5.3 & & 3.4 & 2.6 \\
\hline 2021 & & & &
\end{tabular}

Source: Prepared by the author, on the basis of Economic Commission for Latin America and the Caribbean (ECLAC), "Measuring the impact of COVID-19 with a view to reactivation", Special Report COVID-19, No. 2, Santiago, 21 April 2020; International Monetary Fund (IMF), World Economic Outlook: The Great Lockdown, Washington, D.C., April 2020; and World Bank, Semiannual Report of the Latin America and Caribbean Region: The Economy in the Time of COVID-19, Washington, D.C., April 2020.

The organizations recognize the region's poor economic performance over the last five years, as well as the economic shocks they face as a result of the COVID-19 pandemic. In addition to the aforementioned financial shocks, the contraction in international trade and the decline in commodity prices, it is expected that intraregional trade will fall sharply and tourism will collapse. On top of that remittances, from both abroad (especially from the United States and Spain) and within the region, will tumble by 19\% in 2020 according to World Bank forecasts (2020c).

In terms of economic policy, the major constraint is the fiscal space available to the countries of the region, which is much more limited than it was during the North Atlantic crisis, a point that has been highlighted by several analysts from the Inter-American Development Bank (IDB). Izquierdo and Ardanaz (2020) note that the average deficit of the region's countries was 3\% of GDP in 2019, compared to $0.4 \%$ in 2008 , while the average public debt was $62 \%$ of GDP in 2019 , compared to $40 \%$ in 2008 .

The response of the countries of the region has been in line with international trends. Central banks have provided liquidity (with obvious restrictions for dollarized economies). Governments have adopted fiscal programmes, principally to support the health-care sector and poor and vulnerable households, and measures to reduce or defer payment of some taxes, but the scale of the packages varies widely. According to IDB estimates, the largest packages as a percentage of GDP are those of Brazil, Chile, El Salvador and Peru (Pineda, Pessino and Rasteletti, 2020). Some countries have introduced credit lines or loan guarantees on a large scale, most notably Chile, Colombia, Peru and Uruguay. Despite

\footnotetext{
12 See the projections for Colombia of the Foundation for Higher Education and Development (FEDESARROLLO) (2020), under whose most optimistic scenario GDP is set to fall by $2.7 \%$, but which also considers two alternative scenarios, under which GDP will contract by $5.0 \%$ and $7.9 \%$, which seem more likely. The economic situation is even more complex for Peru, according to preliminary data for the first months of 2020.

${ }^{13}$ According to data from the 10 economies for which information is available dating back to 1900 (see table 1 of the Statistical Appendix of Bértola and Ocampo (2013)), the situation was only worse in 1914 and 1930. However, if the current crisis deepens, as it is very likely to do, it will be the worst in history.
} 
this, the magnitude of support provided by the majority of the region's countries is modest compared to that mobilized by developed countries.

The social repercussions will be evident, as ECLAC has noted (2020b). Moreover, these will occur in a context of social conditions that have been deteriorating since 2014, as a result of poor economic performance. Underinvestment in health care is reflected in weak and fragmented health systems that do not guarantee universal access in many countries. The suspension of face-to-face classes has interrupted school feeding programmes, which several countries have sought to carry out in various ways, including through cash subsidies. The large digital divide means that students from low-income backgrounds are unable to access virtual education. Furthermore, labour informality means that a high proportion of households are left without income, possibly without the support provided by conditional transfers, especially those who are not considered to be poor but are vulnerable. Many micro-, small and medium-sized enterprises (MSMEs) may go bankrupt, which is a very worrying prospect, as they are responsible for creating a high proportion of the jobs in the region. As a result, ECLAC (2020b) estimates, under its medium scenario, that poverty levels will increase from 30.3\% in 2019 to $34.7 \%$ in 2020, equivalent to nearly 29 million more people living in poverty.

\section{An overview of international financial cooperation during the crisis}

The international debate has highlighted that, although the pandemic affected Western Europe and the United States earlier and to a serious degree, and reached developing countries later, the latter are more vulnerable in economic and social terms. There are many reasons for this: containment measures are more costly for people with limited resources in developing countries, who live in small, crowded spaces, sometimes without access to running water; support mechanisms for sectors living in poverty do not exist or do not reach the target population; health-care systems are of a poor quality and do not cover the entire population; and labour informality rates are high and means that containment measures leave a wide range of workers without income. Added to this the fiscal space is narrower and governments' access to credit is more limited. For this reason, there is agreement on the need to adopt ambitious policies to support emerging and developing economies. The financial requirements of these countries are immense: US\$ 2.5 trillion, according to estimates by both IMF (2020d) and the United Nations Conference on Trade and Development (UNCTAD, 2020a).

In the light of these vulnerabilities and needs, the international cooperation agreed upon to date is very limited, in terms of both the measures adopted and the resources to which emerging and developing economies will have access. This is particularly true of the group of middle-income countries, to which almost all Latin American countries belong. As detailed below, the measures taken with respect to lower-income countries have been somewhat more relevant -although still insufficient - and are much more likely to be stepped up.

The shortcomings of multilateral cooperation were particularly evident at the meetings of G20 and the Bretton Woods institutions in April. These meetings will be remembered, not only for being the first in history to be held virtually, but also for the limited international decisions taken in the face of the magnitude of the current crisis.

There have, of course, been expressions of international solidarity. At the end of March, the G20 Leaders committed to "do whatever it takes and to use all available policy tools to minimize the economic and social damage from the pandemic, restore global growth, maintain market stability, and strengthen resilience" (G20, 2020a). The G20 finance ministers and central bank governors expressed something similar in their statements at the meetings of the Bretton Woods institutions. 
However, multilateral measures have not lived up to these promises. The actions being carried out diverge from those provided for in the G20 Global Plan for Recovery and Reform adopted at the G20 Summit in London on 2 April 2009 to address the crisis at that time (G20, 2009). This statement led to the most significant reform of IMF credit lines in the Fund's history, the largest issuance of IMF special drawing rights (SDRs), the capitalization of and massive increase in lending by multilateral development banks, and an ambitious reform of financial regulations. It also eventually led to work beginning on efforts to strengthen international tax cooperation, overseen by the Organization for Economic Cooperation and Development (OECD), to the adoption in 2012 of the IMF institutional view on capital flows, and to the increase and redistribution of IMF quotas. Unfortunately, it took five years to implement the latter because of how long it took the United States Congress to approve the corresponding resources. ${ }^{14}$

Compared to these actions and to the needs of emerging and developing economies, the measures announced at the meetings of the Bretton Woods institutions and parallel actions adopted by the G20 countries have been meagre. This limited international cooperation contrasts with the ambitious domestic policies adopted by developed countries. This is particularly true of the United States, whose domestic policies have been much more vigorous than those adopted to address the 2008-2009 financial crisis and whose support for international actions has been very limited during the current crisis, in contrast to the international leadership it exercised during the 2008-2009 crisis. European countries have also adopted clearly countercyclical policies, but they have been more open to multilateral cooperation. The contrast between the decisive domestic economic policies of developed countries and the limited international cooperation seems to be a key feature of the current crisis.

\section{International monetary cooperation and its effects on Latin America}

The international agenda for monetary issues covers six areas: (i) the provision of international liquidity; (ii) the establishment and expansion of IMF credit lines; (iii) guarantees that IMF will have adequate resources; (iv) the possible coordination of the regulation of capital flows and of the decisions of credit rating agencies; (v) actions aimed at managing the over-indebtedness of several emerging and developing economies; and (vi) the active use and expansion of regional monetary arrangements (Gallagher and others, 2020a).

With regard to liquidity provision, the proposal that has received the most support has been the issuance of SDRs in the amount of at least US\$500 billion, doubling the value of the issuance in 2009. ${ }^{15}$ To make better use of this issuance, a special fund could be created for countries to lend to IMF the SDRs that they do not use, to finance its programmes, or to support other development projects (to capitalize multilateral banks or increase official development assistance). It would be preferable to distribute the SDRs based on criteria other than those used to determine national quotas, ${ }^{16}$ but that would require a change in the IMF Articles of Agreement.

Given the share of Latin American countries in IMF quotas, this issuance of SDRs would imply an increase in their international reserves of US\$ 37.740 billion, equivalent to slightly less than $5 \%$ of those reserves as at the end of 2019 and a little more than $40 \%$ of the net balance of the region's capital and financial account for that year. ${ }^{17}$ The distribution by country would be that shown in table 2; as a percentage of GDP, it would be $0.7 \%$ on average, ranging from $0.6 \%$ to $0.8 \%$ for most of the countries, but it would be higher for those whose GDP in United States dollars has decreased significantly in recent years.

\footnotetext{
${ }^{14}$ For a detailed analysis of these issues, see Ocampo (2017).

${ }^{15}$ For a preliminary version of this proposal, see Gallagher, Ocampo and Volz (2020b). See also Collins and Truman (2020).

${ }^{16}$ As reflected in the long-standing discussions, alternative criteria could be different economies' level of development and demand for international reserves (Ocampo, 2017, chapt. II).

17 The reference data are taken from ECLAC (2019).
} 
Table 2

Latin America: IMF member country quotas

\begin{tabular}{|c|c|c|c|c|c|}
\hline & \multicolumn{3}{|c|}{ IMF quota } & \multicolumn{2}{|c|}{ Effect of a US\$ 500 billion issuance } \\
\hline & Millions of SDRs & Millions of dollars & Percentage of total & Millions of dollars & Percentage of GDP \\
\hline Brazil & 11042 & 15120 & 2.31 & 11574 & 0.62 \\
\hline Mexico & 8913 & 12204 & 1.87 & 9342 & 0.77 \\
\hline Venezuela (Bolivarian Republic of) & 3723 & 5097 & 0.78 & 3902 & 2.52 \\
\hline Argentina & 3187 & 4364 & 0.67 & 3341 & 0.65 \\
\hline Colombia & 2045 & 2799 & 0.43 & 2143 & 0.65 \\
\hline Chile & 1744 & 2388 & 0.37 & 1828 & 0.62 \\
\hline Peru & 1335 & 1827 & 0.28 & 1399 & 0.63 \\
\hline Ecuador & 698 & 955 & 0.15 & 731 & 0.68 \\
\hline Dominican Republic & 477 & 654 & 0.10 & 500 & 0.59 \\
\hline Uruguay & 429 & 588 & 0.09 & 450 & 0.76 \\
\hline Guatemala & 429 & 587 & 0.09 & 449 & 0.62 \\
\hline Panama & 377 & 516 & 0.08 & 395 & 0.61 \\
\hline Costa Rica & 369 & 506 & 0.08 & 387 & 0.65 \\
\hline El Salvador & 287 & 393 & 0.06 & 301 & 1.16 \\
\hline Nicaragua & 260 & 356 & 0.05 & 273 & 2.09 \\
\hline Honduras & 250 & 342 & 0.05 & 262 & 1.10 \\
\hline Bolivia (Plurinational State of) & 240 & 329 & 0.05 & 252 & 0.63 \\
\hline Paraguay & 201 & 276 & 0.04 & 211 & 0.53 \\
\hline Latin America & 36006 & 49302 & 7.55 & 37740 & 0.72 \\
\hline
\end{tabular}

Source: Prepared by the author, on the basis of data from the International Monetary Fund (IMF) and the Economic Commission for Latin America and the Caribbean (ECLAC).

Note: SDR values are converted to dollars at the exchange rate as at 1 May 2020. The estimates as a percentage of GDP correspond to 2018, based on ECLAC estimates for that year.

More ambitious proposals have been put forward, for example to issue SDRs worth US\$ 1 trillion (see, for example, Cardoso and others, 2020). While this would be useful, it would require the explicit approval of the United States Congress because the United States would receive more SDRs than its quota, so Congress cannot simply be informed. This would undoubtedly delay the issuance. Therefore, in order to avoid having to seek Congress's approval, the maximum issuance value must be equal to the total IMF quotas, some US\$ 650 billion.

Although the proposal for a large issuance of SDRs had broad support among IMF member countries and the public, it was vetoed by the United States at the 2020 Spring Meetings of the Bretton Woods institutions, on the grounds that about 70\% of the resources would go to G20 countries, most of whom do not need them (Mnuchin, 2020). Surprisingly, India supported this position. While it is true that just under two fifths of SDRs issued benefit emerging and developing economies, it is also true that this is the only opportunity that these countries have to share in the creation of international money (so-called "seigniorage" benefits). Many low-income countries would benefit significantly from the SDR issuance (Collins and Truman, 2020).

To help create international liquidity, the United States Federal Reserve re-established its currency swap lines with other central banks, following a practice it had already implemented during the North Atlantic crisis. However, only four emerging economies have access to this mechanism: Brazil, Mexico, the Republic of Korea and Singapore. It also set up a new mechanism: a repurchase agreement (repo) instrument, which allows the Federal Reserve to buy back the Treasury Bonds that countries wish to sell; however, this mechanism only benefits those countries with large amounts of foreign exchange reserves.

In terms of creating and extending credit lines, the most important reform has been the doubling of the IMF emergency credit lines, including the rapid financing instrument (RFI) available to middle-income countries. ${ }^{18}$ In the context of simplifying and streamlining procedures, and the absence of ex ante

\footnotetext{
${ }^{18}$ See IMF (2020e) for more details on this and other IMF reforms.
} 
conditionality, this reform has given rise to the rapid approval of a plethora of loans for a wide range of countries. ${ }^{19}$ As at 1 May, seven Latin American countries had made use of these credit lines, totalling slightly more than US\$ 3.3 billion (see table 3); no additional loans were requested by countries of the region in the remainder of the month of May.

Table 3

Rapid financing instrument loans granted to Latin American countries, 2020

\begin{tabular}{lccc}
\hline Country & Millions of SDRs & Date of approval & Millions of dollars \\
\hline Bolivia (Plurinational State of) & 240.1 & 17 April & 328.8 \\
\hline Costa Rica & 369.4 & 29 April & 505.8 \\
\hline Dominican Republic & 477.4 & 29 April & 653.7 \\
\hline Ecuador & 469.7 & 1 May & 643.2 \\
\hline El Salvador & 287.2 & 14 April & 393.3 \\
\hline Panama & 376.8 & 15 April & 515.9 \\
\hline Paraguay & 201.4 & 21 April & 275.8 \\
\hline Total & 2422.0 & & 3316.4 \\
\hline
\end{tabular}

Source: Prepared by the author, on the basis of data from the International Monetary Fund (IMF).

Note: SDR values are converted to dollars at the exchange rate as at 1 May 2020.

In addition to this instrument there are other credit facilities, which some countries took advantage of before the current crisis: the pre-existing flexible credit lines to Mexico and Colombia (the latter was renewed on 1 May) and the new ones granted to Peru and Chile at the end of May, ${ }^{20}$ standby arrangements for Argentina and Honduras, with the latter augmented on 1 June, and the extended arrangement under the extended fund facility for Ecuador, although this was suspended on 1 May ${ }^{21}$ (see table 4). Thus, 13 countries of the region have already received some form of support from IMF. As flexible credit lines act as a kind of insurance for countries, they have not been disbursed yet; disbursements from the other credit lines total just over US\$ 45.7 billion (most of it going to Argentina). The exception in terms of access is the Bolivarian Republic of Venezuela, whose request for a US $\$ 5$ billion loan was rejected in March by IMF on the grounds that there is no clarity among the Fund's member States as to who is the legitimate president of that country.

Table 4

Regular IMF-approved loans to Latin American countries, as of May 2020

\begin{tabular}{|c|c|c|c|c|c|}
\hline \multirow{2}{*}{\multicolumn{2}{|c|}{ Date of approval }} & \multirow{2}{*}{ Maturity } & \multicolumn{2}{|c|}{ Loan value } & \multirow{2}{*}{$\begin{array}{l}\text { Amount disbursed } \\
\text { Millions of dollars } \\
\end{array}$} \\
\hline & & & Millions of SDRs & Millions of dollars & \\
\hline \multicolumn{6}{|c|}{ A. Flexible credit line (FCL) } \\
\hline Mexico & 22 November 2019 & 21 November 2019 & 44563.5 & 61019.9 & 0.0 \\
\hline Colombia & 1 May 2020 & 30 April 2022 & 7849.6 & 10748.3 & 0.0 \\
\hline Peru & 28 May 2020 & 27 May 2022 & 8007.0 & 10963.8 & 0.0 \\
\hline Chile & 29 May 2020 & 28 May 2022 & 17443.0 & 23884.4 & 0.0 \\
\hline \multicolumn{6}{|c|}{ B. Standby Agreements (SBA) } \\
\hline Argentina & 20 June 2018 & 19 June 2021 & 40714.0 & 55748.9 & 43698.8 \\
\hline Honduras $^{\mathrm{a}}$ & 15 July 2019 & 14 July 2021 & 387.2 & 530.2 & 376.3 \\
\hline \multicolumn{6}{|c|}{ C. Extended Fund Facility (EFF) } \\
\hline Ecuador & 11 March 2019 & 10 March 2022 & 3035.0 & 4155.8 & 1653.9 \\
\hline Total & & & 121999.3 & 167051.2 & 45729.0 \\
\hline
\end{tabular}

Source: Prepared by the author, on the basis of data from the International Monetary Fund (IMF).

Note: SDR values are converted to United States dollars at the exchange rate as at 1 May 2020.

a Includes the resources approved under the Standby Credit Facility (SCF) and the increase approved on 1 June 2020; the amount authorized on the latter date includes a disbursement.

${ }^{19}$ Countries may also make use of other IMF instruments, but the allotted value of emergency credit lines is generally less than the country's quota. This was the case for Ecuador, when an RFI was approved for $67.3 \%$ of its quota on 1 May.

20 The flexible credit lines approved for Chile and Peru were 10 and 6 times, respectively, their quotas, much higher than those extended to Mexico and Colombia, which are 5 and 3.8 times their quotas, respectively.

${ }^{21}$ On the same date Ecuador was given access to the emergency credit line. Ecuador will however seek another long-term IMF Ioan. 
Another recommendation that has been discussed is the creation of an IMF swap line. This recommendation was made by IMF staff two years ago (IMF, 2017b), but was rejected by the Executive Board. The G20 Eminent Persons Group on Global Financial Governance subsequently made a similar recommendation (G20 Eminent Person Group on Global Financial Governance, 2018). The IMF created the short-term liquidity line in April in response to this, but it is a very limited response. It will act as a revolving credit line for up to $145 \%$ of the country's quota and without ex ante conditionality, but only member countries "with very strong policies and fundamentals" will have access to it, as is the case with the flexible credit line. However, it is less attractive than the flexible credit line because fewer resources are available and it cannot be combined with other loans from the Fund. Therefore, it is highly likely that it will not be used.

In order to finance the increased demand for credit, IMF needs to expand its resources up to an amount estimated by the Managing Director at US\$ 1 trillion. In this regard, an unfortunate decision was taken last year to defer the increase in quotas until 2023. It is regrettable that the G20 countries have not accelerated this process, given that it is widely recognized by these countries that this should be the Fund's core resource. The additional funds will come from the doubling of the New Arrangements to Borrow (NABs), approved in January 2020, to around US\$ 500 billion, and from bilateral borrowing agreements with several countries. The main contribution of the United States will be its support for NABs.

A fourth line of action that has been proposed by several analysts is the possible coordinated regulation of capital flows in an effort to curb, in particular, capital flight from emerging economies. This action would be in line with the institutional view on capital flows approved by IMF in 2012 (IMF, 2012). Similarly, it has been proposed that credit rating agencies should suspend their downgrades (or the outlook on a rating) during the crisis, as these fuel capital flight. ${ }^{22}$ Mexico and Colombia have already been affected by such decisions, although they have maintained their investment grade rating. Neither G20 nor IMF has taken a position on these issues.

The fifth issue, debt relief, has been the subject of a wide range of proposals, by both institutions (United Nations, 2020, UNCTAD, 2020b) and analysts (see, in particular, Bolton and others, 2020; Brown and Summers, 2020; Reinhart and Rogoff, 2020). This is an area where limited measures have already been taken in relation to low-income countries, but not middle-income countries.

IMF decided that 25 of its most vulnerable members (to which four more could be added in the near future) will be exempt from repayment and interest on their IMF debt obligations for six months, using resources from the Catastrophe Containment and Relief Trust (CCRT). In turn, the G20 countries offered to introduce a debt repayment standstill for countries supported by the International Development Association (IDA) for the rest of 2020, a measure that, according to Brown and Summers (2020), should be extended to the end of 2021. The Paris Club has already taken the necessary decision. It is not clear, however, whether private creditors will adopt it, as the G20 countries have requested. This programme does not cancel the debt, which will remain outstanding and continue to accrue interest.

With regard to middle-income countries, there are critical cases that require debt restructuring. The most important in Latin America are Argentina and Ecuador. While there are proposals for relatively widespread debt repayment standstill for emerging and developing economies (see in particular UNCTAD (2020a and 2020b) and Reinhart and Rogoff (2020)), other proposals favour voluntary mechanisms.

The most interesting proposal is that made by Bolton and others (2020), who suggest the World Bank or regional development banks create a central credit facility to which countries would go voluntarily, and which would facilitate a deferral of amortizations and the use of interests due to fund the response to the health emergency. Countries' obligations would remain in place and therefore the proposed facility would act as a rollover mechanism during the crisis. It would apply to all bilateral and commercial debts on an equal basis. Apart from its voluntary nature, the facility would be subject to intermediation and strict monitoring by the multilateral bank that manages it.

22 See Gallagher and others (2020) for more discussion of this issue. 
Beyond short-term measures, the United Nations and UNCTAD have suggested that an institutional mechanism should be created for restructuring sovereign debt, an issue that has been under discussion for the last two decades, with progress limited to the definition of principles and clauses that allow each country to renegotiate with its creditors, but without a specific institutional framework. ${ }^{23}$

It does not make sense for Latin America to adopt a uniform rule in this area. As figure 2 shows, although risk spreads on bonds issued by emerging economies have increased, they have remained below those seen during the North Atlantic crisis and especially after the Russian default in August 1998 (which, in turn, followed the 1997 Asian crisis). More importantly, with the sharp fall in the yield used as a benchmark to calculate these spreads (10-year United States Treasury Bonds), the bond yields of emerging economies have remained well below those reached during the two previous crises and even those seen during the turmoil in emerging economies' bond markets in 2018.

Figure 2

Risk spreads and yield on emerging economies bonds, 1998-2020

(Emerging Market Bond Index)

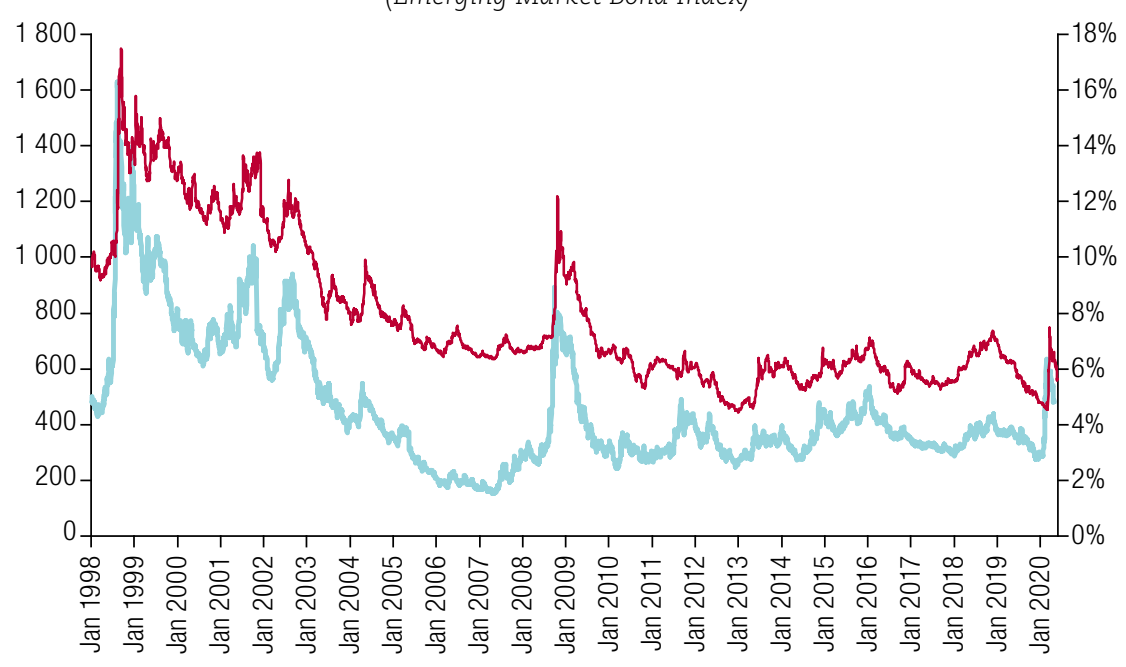

— Yield (right scale) _ Risk spread (left scale)

Source: Prepared by the author, on the basis of data from Bloomberg.

Moreover, bond markets for emerging economies have opened up more quickly than they did after the North Atlantic crisis, when it took just over 12 months after the collapse of the United States' investment bank, Lehman Brothers. This indicates that several investment funds in developed countries are again searching for yield. Two signs of this are the sharp reduction in risk spreads since the end of March (see figure 2) and that capital outflows from emerging economies, which peaked at US\$ 66.1 billion in March, fell to US\$11.3 billion in April and US\$ 10 billion in May, when the flow of hard currency bonds became positive (JP Morgan, 2020).

Eight Latin American countries have already issued bonds: Panama at the end of March, and since mid-April Peru, Guatemala, Mexico, Paraguay, Chile and Colombia, two Colombian public-sector companies (Ecopetrol and Grupo Energía de Bogotá, both with minority private shareholders), two Chilean public-sector companies (Corporación Nacional del Cobre de Chile (CODELCO) and Metro de Santiago) and one Brazilian public-sector company (Petrobras). In addition, the Development Bank of Latin America (CAF) and the Central American Bank for Economic Integration (CABEl) have also issued bonds. Through the hard currency bond markets, US\$24 billion has been raised between mid-April and 1 June 2020.

${ }^{23}$ See Ocampo (2017), chapt. V, for an overview of the discussion. 
In this context, a uniform solution for the debt problems of the countries of the region -and for middle-income countries in general - does not make sense. There are three different situations that should be dealt with separately: (i) countries whose debts need to be thoroughly restructured; (ii) countries that can have recourse, at their discretion, to a debt standstill mechanism such as that proposed by Bolton and others (2020); and (iii) countries with access to new private financing that will continue to service their debts and combine that financing with loans from IMF and the multilateral development banks.

Lastly, it is worth highlighting the role of regional monetary mechanisms. These mechanisms have expanded significantly since the North Atlantic crisis and now have US\$ 585.4 billion at their disposal, equivalent to approximately $60 \%$ of the resources available to IMF, although they are concentrated in European funds and the East Asian Chiang Mai Initiative (Gallagher and others, 2020). Active steps must be taken to deepen the relationship between IMF and regional financing arrangements in order to strengthen the global financial safety net, as has been recognized by both IMF (2017a) and Cheng and others (2018).

This collaboration must be based not only on complementarity, but also the independence of the institutions and respect for their respective mandates and governance structures, and should not follow any hierarchical principles. ${ }^{24}$ Moreover, it is not appropriate to have a formal relationship with IMF programmes, which were the subject of much criticism during the eurozone crisis and is one of the reasons why the resources of the Chiang Mai Initiative have not been used.

In Latin America, there is the Latin American Reserve Fund (FLAR), with eight member countries. This Fund has a very successful record of supporting its members during the various crises they have faced, acting sometimes as a substitute for and sometimes as a complement to IMF resources. In any case, given the limited resources available to FLAR, IMF support is indispensable for large-scale programmes. As part of the measures to strengthen the global financial safety net, an important task is to expand the membership of this regional Fund, until it comprises all Latin American countries.

Table 5 shows the maximum amounts that member countries can receive as loans from FLAR, both in terms of total financing and through its specific credit lines (balance of payments, liquidity and contingency). The total amount available to member countries is just over US\$ 6.5 billion. Nearly all of that amount is available because only one loan is currently active, to Ecuador (for balance of payments) for US\$ 205 million, since the other credits, which had been granted to Costa Rica and the Bolivarian Republic of Venezuela, were settled at the beginning of 2020. As the capital contribution of the Bolivarian Republic of Venezuela to the Fund was used to pay off the loan, the Fund can only give that country limited support now.

Table 5

Capital contributions and maximum credit limits of the Latin American Reserve Fund (FLAR)

(Millions of dollars)

\begin{tabular}{|c|c|c|c|c|c|c|}
\hline \multirow[b]{2}{*}{ Country } & \multirow{2}{*}{$\begin{array}{l}\text { Subscribed } \\
\text { capital }\end{array}$} & \multirow{2}{*}{$\begin{array}{l}\text { Paid-up } \\
\text { capital }\end{array}$} & \multirow{2}{*}{$\begin{array}{l}\text { Maximum } \\
\text { credit limit }\end{array}$} & \multicolumn{3}{|c|}{ Maximum credit limit by type of financial support } \\
\hline & & & & $\begin{array}{c}\text { Balance of } \\
\text { payments support }\end{array}$ & Liquidity facility & $\begin{array}{l}\text { Contingency } \\
\text { facility }\end{array}$ \\
\hline Bolivia (Plurinacional State of) & 328.1 & 256.4 & 666.6 & 666.6 & 282.0 & 538.4 \\
\hline Colombia & 656.3 & 512.9 & 1282.3 & 1282.3 & 512.9 & 1025.9 \\
\hline Costa Rica & 656.3 & 513.1 & 1282.7 & 1282.7 & 513.1 & 1026.1 \\
\hline Ecuador & 328.1 & 256.5 & 666.8 & 666.8 & 282.1 & 538.6 \\
\hline Paraguay & 328.1 & 256.0 & 640.0 & 640.0 & 256.0 & 512.0 \\
\hline Peru & 656.3 & 512.9 & 1282.2 & 1282.2 & 512.9 & 1025.8 \\
\hline Uruguay & 328.1 & 257.0 & 642.4 & 642.4 & 257.0 & 513.9 \\
\hline $\begin{array}{l}\text { Venezuela } \\
\text { (Bolivarian Republic of) }\end{array}$ & 656.3 & 30.7 & 76.7 & 76.7 & 30.7 & 61.3 \\
\hline Total FLAR & 3937.5 & 2595.4 & 6539.7 & 6539.7 & 2646.6 & 5242.0 \\
\hline
\end{tabular}

Source: Prepared by the author, on the basis of data from Latin American Reserve Fund (FLAR).

24 Therefore, the "lead agency" model proposed by IMF (2017a) should not be adopted. 
The great advantage of FLAR is that its programmes do not have any ex ante conditionality, although countries requesting a loan must submit a macroeconomic programme to the Fund. Its main disadvantage is the amount of available resources, so FLAR programmes will almost certainly have to be supplemented by IMF loans. In this case, countries can use FLAR programmes as a complement or as a bridge to an IMF loan, taking advantage of the more streamlined system of the regional Fund to approve financing. Another disadvantage in the current crisis is that FLAR facilities can only be used for balance of payments needs and, therefore, cannot be used to finance governments at a time when demand for resources is very high. Thus, a temporary exception might be appropriate, allowing balance of payments credits to be used for fiscal purposes as well.

\section{Multilateral development banks' cooperation}

The development banks are one of the most important financial instruments available to the international community and a wide range of countries, both developed and emerging and developing economies. The fundamental objective of these institutions is to support long-term development policies - to foster innovation, improve infrastructure, and promote social and regional equity and environmental sustainability -, but their financing can also be used as a countercyclical instrument. Moreover, some projects associated with long-term strategies can be launched during crises to support economic recovery.

The network of development banks encompasses more than 400 institutions worldwide, with total assets of more than US\$ 11 trillion, and they lend some US\$ 2 trillion per year, according to estimates by the French Development Agency (AFD). They include the World Bank Group, as well as a number of regional (such as IDB and CAF), ${ }^{25}$ subregional (CABEI) and interregional banks (the Islamic Development Bank), and a wide range of national banks of varying sizes. One of the major potential benefits is that the institutions act as a network, with the multilateral banks supporting the actions of national banks. If the development banks in this network were to increase their activity by $20 \%$, they could mobilize an additional US $\$ 400$ billion a year; by leveraging private resources, this amount could be doubled (Griffith-Jones, Marodon and Ocampo, 2020).

During the North Atlantic crisis, the multilateral development banks played an important countercyclical role (Ocampo and others, 2011), that was recognized explicitly by the banks themselves and by the economic authorities. The lessons of the past indicated that, in addition to the provision of liquidity in times of crisis by international monetary institutions, it was equally important that multilateral development banks provide long-term financing to support public spending and public and private investment.

Overall, these institutions increased their lending commitments to emerging and developing economies by $71 \%$ between 2008 and 2009; their disbursements grew by 45\% in 2009 and continued to trend upwards in 2010 (Ocampo and others, 2011). This lag in disbursements occurred, despite the measures taken to accelerate them. Interestingly, the response to the needs of middle-income countries was more vigorous than that for low-income countries, with credit commitments to the latter falling from $32 \%$ in 2007 to $22 \%$ in 2009 .

The banks' responses were determined in part by their limited capital. For this reason, as noted in section III, the G20 countries agreed to support the capitalization of the multilateral development banks in the Plan adopted at their London meeting in April 2009. The capitalizations of the Asian Development Bank and the African Development Bank were rapid and massive: a 200\% increase in 2009 in both instances. The capitalization of IDB, approved in March 2010, was less ambitious (about 70\%), happened gradually and was for an amount less than the Latin American and Caribbean countries

\footnotetext{
${ }^{25}$ As reflected by its growing membership and new name, adopted in 2010, CAF is a regional development bank, although the acronym of its former name (the Andean Development Corporation, or Corporación Andina de Fomento) is still used.
} 
had hoped. The World Bank was capitalized in April 2010 and for an even more modest amount. It was part of a set of reforms aimed at increasing the share of emerging and developing economies in the capital of the World Bank.

This countercyclical response moderated, although it certainly did not completely offset, the impact of the sharp drop in private capital flows to these countries. Another area in which multilateral development banks played an important role was in the rapid provision of commercial credit lines, which were used by a wide range of private banks.

Two important lessons to be learned from the response of the multilateral banks during the North Atlantic crisis are, therefore, the need for good mechanisms for rapid disbursements during crises, and for their capital to be replenished more automatically. An alternative to accelerate disbursements that was used during the 2009 crisis and, as we will see, has been used by some institutions during the current crisis, is to allow already-approved loans to be reallocated for other emergency purposes. Another might be to defer debt service payments to the institutions - a practice that could, however, affect banks' credit ratings.

The relative importance of multilateral development bank support to Latin American countries has increased dramatically in recent decades. The World Bank played a leading role until the 1980s. However, as figure 3 shows, the amount it has loaned to the region has remained fairly stable since the 1990s. Nevertheless, the World Bank has continued to play a critical role during crises, as indicated by the increase in its lending to the region in 1998-1999 and especially in 2009-2010.

Figure 3

Multilateral development bank lending to Latin America, 1990-2019

(Billions of dollars)

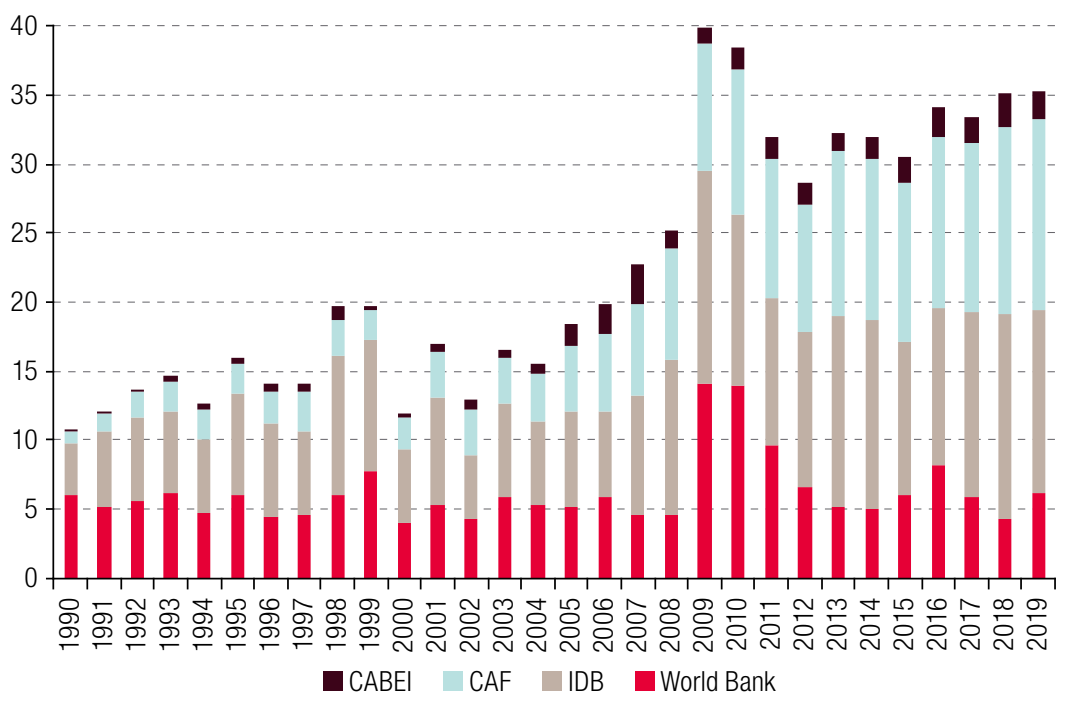

Source: Prepared by the author, on the basis of data from World Bank, Inter-American Development Bank (IDB), Development Bank of Latin America (CAF) and Central American Bank for Economic Integration (CABEI).

The top lender to the region in the 1990s was IDB, before it was challenged by the rapid growth of CAF and CABEl. The uptick in the CAF lending trend has been particularly significant; it has provided as many loans as IDB in the last five years. Although CABEl is a much smaller institution, it has particular importance for the Central American countries and, in recent years, has been rivalling IDB as the main source of financing for the subregion.

It should be noted, however, that the capacity of the World Bank and IDB to respond to the 2008-2009 crisis was much larger than that of CAF and CABEl. This indicates that, during times of 
crisis, the implicit support of the developed countries, in particular the United States, facilitates access to capital markets on advantageous terms. Conversely, CAF and CABEl may be affected, at least partially, by the fact that capital markets are closed to emerging economies during these periods. Nevertheless, both of these development banks joined the recent wave of Latin American bond issuances.

As table 6 shows, CAF was the bank with the highest growth in terms of authorized capital and equity between 2007 (before the outbreak of the North Atlantic crisis) and 2019. Both CAF and CABEI were capitalized earlier than the World Bank and IDB during the 2009 crisis. A new World Bank capitalization was approved in 2018: an increase in the paid-up capital of the International Bank for Reconstruction and Development (IBRD) of US $\$ 7.5$ billion and of the International Finance Corporation (IFC) of US\$ 5.5 billion. Overall, IFC capital has grown much more than that of IBRD since the 2008-2009 crisis (by 95\%), based primarily on the reinvestment of profits. In turn, an increase in the capital available to CABEI from US\$ 5 billion to US\$ 7 billion was approved in December 2019 and made official in April 2020, so it now exceeds CAF in terms of the growth of its capital since 2007.

Table 6

Authorized capital and equity of the multilateral development banks serving Latin America, 2007-2019

(Billions of dollars)

\begin{tabular}{|c|c|c|c|c|c|c|c|c|}
\hline \multirow{2}{*}{ Year } & \multicolumn{4}{|c|}{ Authorized capital } & \multicolumn{4}{|c|}{ Equity } \\
\hline & IBRD & IDB & CAF & CABEI & IBRD & IDB & CAF & CABEI \\
\hline 2007 & 189801 & 100953 & 5000 & 2000 & 39926 & 20353 & 4127 & 1636 \\
\hline 2008 & 189801 & 100938 & 10000 & 2000 & 41548 & 19444 & 4554 & 1708 \\
\hline 2009 & 189918 & 104980 & 10000 & 5000 & 40037 & 20674 & 5287 & 1813 \\
\hline 2010 & 189943 & 104980 & 10000 & 5000 & 37555 & 20960 & 5753 & 1929 \\
\hline 2011 & 193732 & 104980 & 10000 & 5000 & 39683 & 19794 & 6351 & 2028 \\
\hline 2012 & 205394 & 116880 & 10000 & 5000 & 36685 & 20681 & 6865 & 2142 \\
\hline 2013 & 223181 & 128781 & 10000 & 5000 & 39523 & 23550 & 7817 & 2268 \\
\hline 2014 & 232791 & 144258 & 10000 & 5000 & 38985 & 23697 & 8763 & 2396 \\
\hline 2015 & 252821 & 156939 & 15000 & 5000 & 38637 & 25253 & 9524 & 2573 \\
\hline 2016 & 263329 & 170940 & 15000 & 5000 & 37063 & 26460 & 10474 & 2723 \\
\hline 2017 & 268937 & 170940 & 15000 & 5000 & 39798 & 32247 & 11122 & 2831 \\
\hline 2018 & 274730 & 170940 & 15000 & 5000 & 41844 & 32929 & 11863 & 3198 \\
\hline 2019 & 279953 & 170940 & 15000 & 5000 & 42115 & 33871 & 12797 & 3300 \\
\hline \multicolumn{9}{|c|}{ Growth } \\
\hline 2007-2019 & $47.5 \%$ & $69.3 \%$ & $200.0 \%$ & $150.0 \%$ & $5.5 \%$ & $66.4 \%$ & $210.1 \%$ & $101.8 \%$ \\
\hline
\end{tabular}

Source: Prepared by the author, on the basis of data from International Bank for Reconstruction and Development (IBRD), Inter-American Development Bank (IDB), Development Bank of Latin America (CAF) and Central American Bank for Economic Integration (CABEl).

All the banks providing services to the region have adopted special support measures during the current crisis: granting special, fast-tracked credit lines to tackle the crisis, albeit with modest resources; increasing the scale of credit programmes, within their capital restrictions; streamlining credit approvals; and, in several cases, allowing already-approved loans to be reallocated to meet urgent needs.

According to the remarks delivered by the World Bank Group President to the Joint Ministerial Committee of the Boards of Governors of the Bank and the Fund on the Transfer of Real Resources to Developing Countries (Development Committee) on 17 April 2020, the programme to address the crisis is based on three pillars: (i) to protect the poorest and most vulnerable households; (ii) to support businesses and save jobs; and (iii) to help developing countries implement emergency health operations and strengthen economic resilience (World Bank, 2020d). Two important elements of the packages announced are the significant weight of resources going to low-income countries - thus correcting one of the problems with the World Bank's actions during the crisis a decade ago - and the emphasis on measures aimed at 
the private sector carried out through IFC, offering international trade loans, working capital support and medium-term financing to private companies struggling with breaks in their supply chains.

The immediate support package approved by the World Bank in mid-March made US\$ 14 billion of new financing available to countries expeditiously. Fast-track facility resources have already been disbursed to six Latin American countries - Argentina, Ecuador, El Salvador, Honduras, Paraguay and Uruguay - in April and May, although the loans were for modest amounts, totalling US\$135 million (each country received US\$20 million each, except Argentina, which was loaned US\$ 35 million).

In addition to the emergency programme, in late March 2020, the World Bank approved a US\$ 160 billion package covering the next 15 months. This is substantially more than the annual average of World Bank loans approved in 2009-2010, which was US\$ 64.4 billion. This broader package includes emergency loans and the possible reallocation of funds from existing projects. Five Latin American countries have already benefited from this broader package in April and May: Colombia, the Dominican Republic, Honduras, Panama and the Plurinational State of Bolivia. Together with emergency credits, the World Bank approved US\$1.119 billion in lending to Latin America in April and May, which is higher than the monthly average for the last five years, but still less than the monthly average approved for the region in 2009-2010.

The President of the World Bank Group told the G20 finance ministers in March that recovery policies must be linked to structural reforms: "Countries will need to implement structural reforms to help shorten the time to recovery and create confidence that the recovery can be strong" (World Bank, 2020e). It is regrettable that he made this link to structural reforms, given that an increasing number of emerging and developing economies have rejected this view, as it bears very little relation to the economic emergency.

The programme announced by IDB to address the crisis is underpinned by the principle that the virus affects not only human health, but also the economy, the survival of many firms and families' finances, and that, if it is not properly managed, can create a social crisis. The Bank has identified four priority areas for its support programmes: (i) the immediate public health response; (ii) safety nets for vulnerable populations, specifically measures to protect the income of the most affected populations through existing transfer programmes, as well as extraordinary transfers to workers in the informal sector and support for companies in sectors particularly affected by the crisis; (iii) assistance to small and medium-sized enterprises (SMEs), through financing programmes and liquidity guarantees, foreign-trade financing, loan restructuring and support for strategic supply chains; and (iv) fiscal policies for the amelioration of economic impacts, in the form of support to countries in designing and implementing fiscal measures to finance the response to the crisis, plans for the execution of expenditures and public procurement, and measures to support the economic recovery.

The programme includes an adjustment of IDB lending instruments and a streamlining of approving processes. In terms of resources, it includes the allocation of an additional US $\$ 3.2$ billion to the loan programme initially stipulated for 2020. These funds, added to the available resources already programmed for this year, would make up to US\$12 billion available to countries. This amount, however, is very similar to the annual lending average over the last five years, which is why, more than the amount loaned, the priority has been reallocating resources and accelerating loan approvals, which have increased from US\$2.6 billion to US\$ 3.7 billion in the first five months of 2020 compared to 2019. In immediate terms, it has also offered countries the possibility of reallocating resources from already approved loans to meet the new priorities created by the emergency, in an amount equivalent to $10 \%$ of each loan or up to US\$ 50 million (whichever is greater). IDB Invest, the private sector arm of the IDB Group, has contributed an additional US\$ 5 billion to support the financing of production chains and trade, and banks in a context of severe liquidity constraints.

In addition, both IDB and non-regional partners are providing technical cooperation resources that prioritize exchange and learning platforms. Analyses of the effects of the various dimensions of the crisis and of alternative methods to address them, which are published in the blog "Ideas Matter", have also been very important. 
Meanwhile, CAF is helping to tackle the emergency through four specific actions. The first is a contingent credit line, approved in early March, of up to US\$300 million (up to US\$ 50 million per country) to respond quickly to the needs of public health systems. The second is a rapid disbursement emergency credit line, approved in late March, of up to US\$ 2.5 billion, to streamline the approval of operations that support the emergency measures being adopted by countries. The third is the possibility of reprogramming existing loans, even allowing their objectives and destinations to be changed. The fourth is prioritizing collaboration with national development banks to support SMEs. It is not clear, however, whether CAF can substantially increase its credits over the high levels reached in 2018-2019 without additional capital. In any case, it has accelerated loan approvals in the first five months of the year to US\$ 3.9 billion, compared to US\$2.3 billion in 2019. In addition, non-reimbursable technical cooperation resources of up to US $\$ 400,000$ per country are available, which several members have already received.

Lastly, CABEl launched the Emergency of Support and Preparedness Programme for COVID-19 and Economic Reactivation on 31 March 2020, worth US\$ 1.96 billion. The programme includes three credit components: US\$1 billion in loans to support the liquidity management of central banks of founding and non-founding regional members; 26 US\$ 600 million in emergency budget support; and US\$ 350 million in liquidity support for the financial sector in countries to support MSMEs. Unlike IDB and CAF, the recent capitalization of CABEl and the bond issuance at the end of April will allow it to significantly increase its lending, up to around US $\$ 3$ billion, representing growth of $45 \%$ in relation to the average for the last five years.

In the absence of additional capitalizations for IDB and CAF - the two most important multilateral banks for Latin America - the resources provided by these institutions to the countries of the region will increase modestly compared to the response to the North Atlantic crisis, even though the current crisis is more severe. CABEl is the notable exception. For this reason, actions in this area, as well as on the monetary front, must be strengthened substantially to tackle the severe economic and social problems caused by the COVID-19 pandemic.

\section{Conclusions}

The current economic crisis will be remembered, not only as the worst since the Great Depression and one in which developed countries have adopted ambitious domestic policies, but also for the limited multilateral financial cooperation that has been agreed. This is particularly true of measures to support middle-income economies. Actions to help lower-income countries have been more substantial, but also insufficient. Clearly, the multilateral actions have fallen far short of the commitment "to do whatever it takes", made by the G20 Leaders at the end of March 2020.

In the area of international monetary cooperation, the most frustrating aspects have been the refusal to issue IMF SDRs, the failure to take a decision on or even to suggest bringing forward the increase in IMF quotas, and the lack of collective measures to tackle capital flight from emerging economies and to stop credit ratings agencies from downgrading countries. Latin American countries have benefited from IMF emergency loans, albeit for modest amounts, and flexible credit lines (in the case of four countries), and can access other IMF facilities if they so wish. The eight member countries of FLAR are also able to benefit from the support of this regional body, but it is recommended that they be allowed, at least temporarily, to use those resources for fiscal purposes. Efforts to expand the membership of FLAR should also be stepped up as a result of the crisis.

With regard to foreign debt, it is recommended that a diverse approach be adopted that supports ambitious foreign debt restructuring for countries that need it (Argentina and Ecuador) and creates a

\footnotetext{
${ }^{26}$ The founding regional members are Costa Rica, El Salvador, Guatemala, Honduras and Nicaragua, and the non-founding regional members are Belize, the Dominican Republic and Panama.
} 
voluntary and multilaterally monitored debt standstill mechanism for those economies that may require such support. Meanwhile, the early recovery of the emerging economies' bond market that began in mid-April is good news, and has allowed several countries and public-sector firms, as well as CAF and CABEl, to access private financing. In addition to short-term measures, the creation of an institutional mechanism to renegotiate sovereign debts must be put back on the table.

The multilateral development banks have created several emergency credit lines to address the crisis, streamlined their procedures and several of them have allowed loans already approved to be rechannelled to tackle the health, social and economic emergencies caused by the COVID-19 pandemic. In Latin America, the work of CABEl, supported by the recent capitalization, has been the most noteworthy. The World Bank has increased its lending to the region, although these loans amount to less than those granted during the North Atlantic crisis. The two main multilateral banks for the region, IDB and CAF, have also adopted important measures, but they have reached the limit of their lending capacity and need to be recapitalized to provide more robust support to the countries of the region during the crisis. On the whole, in terms of resources, the multilateral banks' programmed support for Latin American countries is, so far, insufficient.

Lastly, the economic problems of a wide range of Latin American countries were already acute during the five years preceding the current crisis, and the sluggish growth during those years acted as a drag on and partly reversed the improvement in social indicators seen since the beginning of the century. Economic growth in the region has also been slow over the past three decades, and the region is still beset by multiple social problems, including having one of the worst income distributions in the world. Moreover, a contraction in global economic growth and trade, and fewer opportunities for Latin American migrants will be the grim legacy left behind by the crisis, among other adverse effects.

Therefore, beyond the crisis, the region's development strategy must be reformulated, to include a big push for scientific and technological development, reindustrialization, solid and depoliticized support for regional integration, and a firm commitment to reducing inequality and to making a major contribution to global efforts to combat climate change and protect biodiversity. On all these issues, which are beyond the scope of this article, the support of the development banking system will also be critical.

\section{Bibliography}

Baldwin, R. and B. Weder di Mauro (eds.) (2020), Mitigating the COVID Economic Crisis: Act Fast and Do Whatever It Takes, London, Centre for Economic Policy Research (CEPR).

Bértola, L. and J. A. Ocampo (2013), El desarrollo económico de América Latina desde la independencia, Mexico City, Fondo de Cultura Económica.

Bolton, P. and others (2020), "Necessity is the mother of invention: how to implement a comprehensive debt standstill for COVID-19 in low- and middle-income countries", London, Centre for Economic Policy Research (CEPR), 21 April [online] https://voxeu.org/article/debt-standstill-covid-19-low-and-middle-income-countries.

Brooks, R. and J. Fortun (2020), "COVID-19 capital flow exodus from EM", Global Macro Views (GMV), No. 3830, Washington, D.C., Institute of International Finance (IIF), 2 April.

Brown, G. and L. H. Summers (2020), "Debt relief is the most effective pandemic aid", Project Syndicate, 15 April [online] https://www.project-syndicate.org/commentary/debt-relief-most-effective-covid19assistance-by-gordon-brown-and-lawrence-h-summers-2020-04.

Cardoso, F. H. and others (2020), "A roadmap for confronting COVID-19 in Latin America", Americas Quarterly, 15 April [online] https://www.americasquarterly.org/article/a-roadmap-for-confronting-covid-19-in-latin-america/.

Cheng, G. and others (2018), "IMF-RFA collaboration: motives, state of play, and way forward. A joint RFA staff proposal", Discussion Paper Series, No. 4, Luxembourg, Publications Office of the European Union, October [online] https://www.esm.europa.eu/sites/default/files/esmdiscussionpaper4.pdf.

Collins, C. and E. Truman (2020), "IMF's special drawing rights to the rescue", 10 April, Peterson Institute for International Economics (PIIE) [online] https://www.piie.com/blogs/realtime-economic-issues-watch/ imfs-special-drawing-rights-rescue. 
CPB (Netherlands Bureau of Economic Policy Analysis) (n/d), "World trade monitor" [online] https://www. cpb.nl/en/worldtrademonitor.

ECLAC (Economic Commission for Latin America and the Caribbean) (2020a), "Measuring the impact of COVID-19 with a view to reactivation", Special Report COVID-19, No. 2, Santiago, 21 April. (2020b), "The social challenge in times of COVID-19", Special Report COVID-19, No. 3, Santiago, 12 May. (2019), Preliminary Overview of the Economies of Latin America and the Caribbean 2019, (LC/ PUB.2019/25-P), Santiago.

FEDESARROLLO (Foundation for Higher Education and Development) (2020), Prospectiva económica, L. F. Mejía, X. Cadena and M. E. Delgado (eds.), Bogotá, 30 April.

Gallagher, K. P., J. A. Ocampo and U. Volz (2020), "It's time for a major issuance of the IMF's special drawing rights", Financial Times, 20 March [online] https://ftalphaville.ft.com/2020/03/20/1584709367000/lt-stime-for-a-major-issuance-of-the-IMF-s-Special-Drawing-Rights/.

Gallagher, K. P. and others (2020), "Safety first: expanding the global financial safety net in response to COVID-19", GEGI Working Paper, No. 0037, Boston, Boston University, April.

Georgieva, K. (2020), "Confronting the crisis: priorities for the global economy", Washington, D.C., International Monetary Fund (IMF), 9 April [online] https://www.imf.org/en/News/Articles/2020/04/07/sp040920SMs2020-Curtain-Raiser.

Griffith-Jones, S., R. Marodon and J. A. Ocampo (2020), "Mobilizing $\$ 400$ billion: using the visible hand of development banks", Washington, D.C., Center for Global Development, 10 April [online] https://www. cgdev.org/blog/mobilizing-400-billion-using-visible-hand-development-banks.

G20 (Group of 20) (2020a), "Extraordinary G20 Leaders' Summit: statement on COVID-19”, paper presented at the Extraordinary G20 Leaders' Summit, Riyadh, 26 March [online] http://www.g20.utoronto.ca/2020/2020g20-statement-0326.html.

(2020b), "Communiqué", paper presented at the Virtual Meeting of the G20 Finance Ministers and Central Bank Governors, Riyadh, 15 April [online] http://www.g20.utoronto.ca/2020/2020-g20-finance-0415.html. (2009), "Global Plan for Recovery and Reform", paper presented at the G20 Leaders' Summit, London, 2 April [online] http://www.g20.utoronto.ca/2009/2009communique0402.html.

G20 Eminent Persons Group on Global Financial Governance (2018), Making the Global Financial System Work for All: Report of the G20 Eminent Persons Group on Global Financial Governance, October [online] https://www.globalfinancialgovernance.org/assets/pdf/G20EPG-Full\%20Report.pdf.

IDB (Inter-American Development Bank) (2020), "COVID-19: situation update in Latin America and the Caribbean" [online] https://www.iadb.org/en/coronavirus/current-situation-pandemic.

IMF (International Monetary Fund) (2020a), World Economic Outlook: The Great Lockdown, Washington, D.C., April.

(2020b), Global Financial Stability Report: Markets in the Time of COVID-19, Washington, D.C., 14 April. (2020c), "Chapter 1: policies to support people during the COVID-19 pandemic", Fiscal Monitor, Washington, D.C., 15 April.

(2020d), "Press briefing by Kristalina Georgieva following a conference call of the International Monetary and Financial Committee", Washington, D.C., 27 March [online] https:/www.imf.org/en/News/Articles/2020/03/27/ tr032720-transcript-press-briefing-kristalina-georgieva-following-imfc-conference-call.

(2020e), "The managing director's global policy agenda, spring meetings 2020: exceptional times, exceptional action", Policy Papers, No. 20/020, Washington, D.C., 14 April.

(2020f), "IMF Primary Commodity Prices", June [online] https://www.imf.org/en/Research/commodity-prices. (2017a), "Collaboration between regional financing arrangements and the IMF", Policy Papers, Washington, D.C., 31 July.

(2017b), "Adequacy of the global financial safety net - Considerations for fund toolkit reform", Policy Papers, Washington, D.C., 19 December.

(2012), "The liberalization and management of capital flows: an institutional view", Policy Papers, Washington, D.C., 14 November.

Izquierdo, A. and M. Ardanaz (2020), "Fiscal policy in the time of coronavirus: constraints and policy options for Latin American and Caribbean countries", Ideas Matter, Inter-American Development Bank (IDB), 31 March [online] https://blogs.iadb.org/ideas-matter/en/fiscal-policy-in-the-time-of-coronavirus-constraints-andpolicy-options-for-latin-american-and-caribbean-countries/.

JP Morgan (2020), EM Flows Weekly, 28 May.

Levy, S. (2020), "Suggestions for the emergency", COVID-19 Policy Documents Series, No. 2 (UNDP LAC C19 PDS 2), New York, United Nations Development Programme (UNDP), March. 
Maddison, A. (2010), "Maddison database 2010", Groningen Growth and Development Centre, University of Groningen [online] https://www.rug.nl/ggdc/historicaldevelopment/maddison/releases/maddisondatabase-2010.

Mnuchin, S. (2020), “U.S. Treasury Secretary Steven T. Mnuchin's Joint IMFC and Development Committee Statement", United States Department of the Treasury, 16 April [online] https://home.treasury.gov/news/ press-releases/sm982.

Nuguer, V. and A. Powell (coords.) (2020), "Policies to fight the pandemic", Latin American and Caribbean Macroeconomic Report, Washington, D.C., Inter-American Development Bank (IDB), April.

Ocampo, J. A. (2020), "Can Latin America avoid another lost decade?", Project Syndicate, New York, 3 January [online] https://www.project-syndicate.org/commentary/latin-america-lost-decade-low-growthby-jose-antonio-ocampo-2020-01?barrier=accesspaylog. (2017), Resetting the International Monetary (Non)System, Oxford, Oxford University Press.

Ocampo, J. A. and others (2011), "La gran recesión y el mundo en desarrollo", Cooperación para el desarrollo en tiempos de crisis, J. A. Alonso and J. A. Ocampo (coords.), Mexico City, Fondo de Cultura Económica.

Pineda, E., C. Pessino and A. Rasteletti (2020), "Policy and fiscal management during the pandemic and postpandemic in Latin America and the Caribbean", 1 May [online] https://blogs.iadb.org/gestion-fiscal/en/ policy-and-fiscal-management-during-pandemic-and-post-pandemic-latin-america-and-the-caribbean/.

Reinhart, C. and K. Rogoff (2020), "Suspend emerging and developing economies' debt payments", Project Syndicate, New York, 13 April [online] https://www.project-syndicate.org/commentary/suspend-emergingand-developing-economies-debt-payments-by-carmen-reinhart-and-kenneth-rogoff-2020-04.

Stiglitz, J. E. and others (2020), "How the economy will look after the coronavirus pandemic", Foreign Policy, Washington, D.C., 15 April [online] https://foreignpolicy.com/2020/04/15/how-the-economy-will-lookafter-the-coronavirus-pandemic/.

Tooze, A. (2020), "The coronavirus is the biggest emerging markets crisis ever", Foreign Policy, Washington, D.C., 28 March [online] https://foreignpolicy.com/2020/03/28/coronavirus-biggest-emerging-marketscrisis-ever/.

UNCTAD (United Nations Conference on Trade and Development) (2020a), "The COVID-19 shock to developing countries: towards a 'whatever it takes' programme for the two-thirds of the world population being left behind", Trade and Development Report Update (UNCTAD/GDS/INF/2020/2), Geneva, March.

(2020b), "From the great lockdown to the great meltdown: developing country debt in the time of COVID-19", Trade and Development Report Update (UNCTAD/GDS/INF/2020/3), Geneva, April.

United Nations (2020), Debt and COVID-19: A Global Response in Solidarity, New York, 17 April [online] https://www.un.org/sites/un2.un.org/files/un_policy_brief_on_debt_relief_and_covid_april_2020.pdf.

World Bank (2020a), Commodity Markets Outlook: Implications of COVID-19 for commodities, Washington, D.C., April.

(2020b), Semiannual Report of the Latin America and Caribbean Region: The economy in the time of COVID-19, Washington, D.C., April.

(2020c), "COVID-19 crisis through a migration lens", Migration and Development Brief, No. 32, Washington, D.C., April.

(2020d), "World Bank Group President Malpass: remarks to the Development Committee", 17 April [online] https://www.worldbank.org/en/news/statement/2020/04/17/world-bank-group-president-malpassremarks-to-the-development-committee.

(2020e), "Remarks by World Bank Group President David Malpass on G20 Finance Ministers Conference Call on COVID-19", 23 March [online] https://www.worldbank.org/en/news/speech/2020/03/23/remarksby-world-bank-group-president-david-malpass-on-g20-finance-ministers-conference-call-on-covid- 19 .

WTO (World Trade Organization) (2020), "Trade set to plunge as COVID-19 pandemic upends global economy”, Press Release (Press/855), Geneva, 8 April [online] https://www.wto.org/english/news_e/ pres20_e/pr855_e.pdf. 